\title{
KEEPING LEGAL HISTORY MEANINGFUL
}

\author{
Richard H. Pildes \\ A Response to Charles A. Heckman's \\ "Keeping Legal History 'Legal' and Judicial Activism in \\ Perspective: A Reply to Richard Pildes"
}

The end of Reconstruction is conventionally identified as the 1876 disputed Presidential election and subsequent withdrawal of federal troops from the South. Yet for nearly a generation after that date, black Americans' political participation remained surprisingly robust. Even in the 1890 s, half of black men continued to vote in key gubernatorial races in Southern states. More remarkably still, inter-racial fusion coalitions controlled the state legislature in the border state of North Carolina as late as 1898 (similar coalitions endured just as late in parts of Texas). Contrary to deterministic views of the history of race in late 19th century America, the structure of the 20th century Southern racial order-segregation and the virtual elimination of black citizens from democracy - was not locked into place by some essential, fixed, organic structure of "the white South" the moment federal troops withdrew. Far from monolithic and unified, white southerners were vehemently, even violently, fractured; the interests and passions they pressed on post-Reconstruction state politics expressed dramatically opposed visions for government. The contest over black disfranchisement - and it was a contest was inextricably bound up with this death-struggle between contending white factions: oligarchic, large, land-holding elites versus poorer, populist whites from outside the former plantation regions who had long resisted, but with sporadic success, the political domination of the oligarchs. Black votes threatened to tip this balance of power.

A generation after the turbulence of this era, though, the comprehensive regime of white supremacy had emerged. So,

1. Professor of Law, New York University. Thanks to Larry Kramer for comments. Thanks also to Gretchen Feltes, for excellent library assistance, as always. 
too, had one party political monopolization of Southern politics, in the form of the Democratic Party. Blacks had been eliminated from politics and socially segregated. Because this regime endured until the modern civil rights era, it is easy to think its reign natural and inevitable. But this regime emerged through the struggles of this era; it had to be self-consciously constructed, brick by brick, year by year, in conflicts with opposing white factions close to equipoise, in battles whose outcome was often in doubt. At critical junctures, the triumph of one set of forces would send politics and culture down a particular path, a path that would then make the next step easier for those forces.

Contrary, also, to the limited attention these issues have received in modern constitutional scholarship, the forms of law played a central role in crystallizing the fluid, open-ended welter of events into a particular form. First, law was an instrument the oligarchs used to leverage fragile control at one moment into more persistent form; through laws that gerrymandered election districts, and through statutory suffrage restrictions, this faction undermined its political competition in incremental stages. These efforts then culminated in the new disfranchising constitutions and constitutional amendments of 1890-1908 that, in the most enduring legal form available, froze into place an electorate drained of nearly all black, and many poor white, voters. Second, desperate black citizens, viewing the federal courts as their last hope, created and arranged financing for a social and litigation movement to challenge constitutionally these disfranchising constitutions. But in Giles v. Harris, ${ }^{2}$ a divided Court, in an opinion by Justice Holmes, resoundingly slammed the door on this last possible avenue of challenge. The uncertain, shifting, sharply contested possibilities that had characterized racial issues in the South on the eve of disfranchisement were now definitively closed. The white, reactionary, ruling elite, in the form of the one-party Democratic South, was in the saddle, and no national institution was prepared to do anything-rhetorically, culturally, politically, or legally-about it. Given that neither the President nor Congress was willing by this time to take any initiative in defending the Fifteenth Amendment, itself the capstone of Reconstruction, Giles might well be said to mark the final moment in the demise of Reconstruction. 
These are the critical points in Democracy, AntiDemocracy, and the Canon. ${ }^{3}$ Professor Heckman's warm words for the quality of the historical work underlying those claims are much appreciated. But while he apparently accepts this broader historical analysis, Professor Heckman writes to argue that we should locate the Supreme Court's abnegation not in Giles, but in Mills v. Green, ${ }^{4}$ eight years earlier. Perhaps one should not worry much about whether the Supreme Court's acceptance of disfranchisement, the subject of little scholarly analysis until now, is better identified with Mills or Giles. The aims of The Canon, after all, were to explore the relationship of law to culture and politics, to expose the Supreme Court's role in the national toleration of disfranchisement, and to bring issues of democracy - and the destruction of democracy through law-closer to the center of constitutional thought. The specific case that best illuminates these themes is, perhaps, of less significance than that the themes be illuminated. Nonetheless, I must insist that Professor Heckman has focused on the individual legal notes in Giles while failing to hear the melody being played. In his fixation on the most technical aspects of the Giles litigation, Professor Heckman has missed the political, cultural, historical, and legal significance of Giles as a defining moment.

Giles was not, of course, the first case in which courts of this era concluded that equity would not enforce "political rights." Professor Heckman seems to think that Giles could be of substantive significance only if it had newly conceived this doctrine. That is akin to arguing that Plessy v. Ferguson ${ }^{5}$ was not all that noteworthy because the Court, having already held that interracial adultery could be punished more severly than same-race adultery, had already established that the Fourteenth Amendment did not require colorblindness. ${ }^{6}$ Giles was significant because it was prepared to hold political rights non-remediable in equity even in a context that presented the most radical threat to the constitutional order that the Court had faced under the Fifteenth Amendment. And Giles was momentous because the de-

3. Richard H. Pildes, Democracy, Anti-Democracy, and the Canon, 17 Const. Comm. 295 (2000).

4. 159 U.S. 651 (1895).

5. 163 U.S. 537 (1896).

6. See Pace v. Alabama, 106 U.S. 583 (1883) 
cisive actors of the time understood it in these terms, as a fundamental constitutional test of whether massive disfranchisement would be permitted under the shadow of the Fifteenth Amendment. Most dramatically, the language in which the Court, through Justice Holmes, justified applying the doctrine, even in such an extreme context, baldly proclaimed that the Court would not entertain head-on challenges to disfranchisement in any form of action - equitable, legal, or any other. ${ }^{7}$

Giles' lawyer framed the issue in the broad, test-case terms in which blacks who were active in the litigation, supported it, and were watching it, understood the stakes: "a more highhanded and flagrant case of the nullification of the fourteenth and fifteenth Amendments to the Constitution of the United States and repudiation of their solemn guarantees to the negroes of America can never be presented to the courts of the country." "Giles' brief concluded in ways that could hardly have framed the confrontation more momentously: "And this court must know that the honor of this nation is bound to suffer in the estimation of the world if its solemn constitutional guarantees made to the negro shortly after the late civil war, when his conspicuous service on behalf of the Union was fresh in the minds of the American people, are allowed to go unenforced, and to become a dead letter in a well-established case like this." To dispute that the stakes were high would be foolhardy, given that the new Alabama Constitution of 1901 contained, as later historians have remarked, "the most elaborate suffrage requirements that have ever been in force in the United States."10 Moreover, Jackson Giles was hardly an idiosyncratic, well-to-do plaintiff off on a solitary litigation lark. Giles, a janitor in the federal courthouse in Montgomery, Alabama, was president of an Alabama organization called the Colored Men's Suffrage Association. More work needs to be done on the history of this intriguing organization, but it appears that this was the central organizational vehi-

7. The Court formally left open the possibility of a damages action, but no court ever acted on that option.

8. Brief for Appellant in Giles v. Harris, No. 493, at 4 (October Term, 1902).

9. Id. at 16. Earlier, the brief had further framed the issue, not in the narrow procedural terms Professor Heckman sees, but in the broad terms that the case was obviously meant to raise: "To the negro, if the guarantees of the fourteenth and fifteenth amendments are stricken from under him, under the pretense of the want of jurisdiction in the courts of the United States to enforce them, he has only one other guarantee between him and actual slavery: that is the one contained in the thirteenth amendment. What reason would he have to hope for protection under that one, should the Southern States by similar methods undertake to deprive him of that guarantee?" Id. at 7.

10. See Pildes, 17 Const. Comm. at (cited in note 3). 
cle blacks created in Alabama to challenge disfranchisement. Giles brought his action on behalf of 5,000 similarly situated "negro citizens" of Montgomery County. His lawyer, Wilford H. Smith of New York City, was the personal lawyer and friend of Booker T. Washington. Smith had come to Alabama at Washington's urging to handle the case, and Washington had secretly raised the funds to support the litigation-indeed, so concerned was Washington that he was risking his public reputation that he wrote his correspondence about the litigation in code. To avoid the defects of previous litigation, Smith pulled together extensive newspaper reports chronicling the comparative numbers of blacks and whites disfranchised in different counties of Alabama by the new constitution. " Similar suits were filed in Louisiana and Virginia, which appear to have awaited the result in Giles. ${ }^{12}$ The financial, organizational, personal, and emotional resources the black community invested in Giles were substantial-and these were scarce resources that could not be marshalled time and time again in communities where public defiance frequently met economic or more violent forms of intimidation. Professor Heckman's focus on the bare legal text of Giles fails to appreciate the unique effort mobilized to press the litigation, that the litigation was at one and the same time one of the only cards, as well as the last card, the activist black community had to play to challenge disfranchisement in the national political arena.

Alabama's lawyer also urged the Court to confront disfranchisement head-on, instead of framing the case in narrow procedural or technical terms. He forthrightly admitted that the Alabama Constitution of 1901 employed tests that would exclude "many whites" as well as "the mass of the negro population" from the vote. ${ }^{13}$ Alabama's lead argument, and most of its brief, was devoted to the fundamental, substantive constitutional merits. Thus, the state urged that the purposes of the constitution's drafters was irrelevant; that the constitution on its face did not single out negroes for disfranchisement; that if the constitution were administered in a discriminatory way, that was a defect that could not be traced to the constitution itself and hence could not be remedied by attacking the constitution itself; and that Ala-

11. J. Morgan Kousser, Colorblind Injustice: Minority Voting Rights and the Undoing of the Second Reconstruction 322 (U. of North Carolina Press, 1999).

12. My collaborator, Professor Rebecca J. Scott, has done research which suggests that Louisiana officials put the challenge to disfranchisement on hold there, and then after Giles pressed the courts to resolve it, after the state brought forward arguments based on Giles itself as to why the case should be dismissed.

13. Brief for Appellee in Giles v. Harris, No. 493 at 8 (1902). 
bama had the obvious right to exclude those who could not meet the "good character" and "understanding" tests. Alabama pressed the Court to address these underlying substantive issues: "It is important, for obvious reasons, that the latter question [the substantive merits of whether disfranchisement was constitutional], if possible, be authoritatively settled..."14 Both sides, therefore, framed the case as the culminating act in the disfranchisement saga.

The Court, too, took on the challenge in these terms. Holmes recognized that the stakes went well beyond doctrinal principles previously established. Thus, Holmes nodded toward the "traditional limits" that precluded proceedings in equity to remedy political wrongs. ${ }^{15}$ But he hardly considered that a sufficient answer, given the magnitude of the issues involved. For immediately after restating this traditional principle, Holmes went on to explain why that principle was put in issue by the massive, constitutional disfranchisement of which Giles complained in his proto-class action: "But we cannot forget that we are dealing with a new and extraordinary situation, and we are unwilling to stop short of the final considerations which seem to the United States to dispose of the case." ${ }^{\prime 6}$ The precise point of Giles's argument was that traditional equitable restraints on remedying deprivations of political rights should not preclude relief when a state engaged in a conspiracy to nullify the Reconstruction Amendments - in as "high-handed and flagrant" a manner as imaginable. As Giles' lawyer put it, while money damages might adequately remedy routine voting-rights violations, it would be "absurd" to think such an award, "however large," could be adequate when massive, race-based, constitutional disfranchisement was involved. ${ }^{17}$ Justice Harlan, in dissent, similarly went out of his way to observe that "the case involves questions of considerable importance...." Given this context, it is rather an understatement, at the least, to describe Giles as a case "basically concerned with procedural issues of no lasting consequence." 19

\footnotetext{
14. Id. at 2 .

15. 189 U.S. at 486 (citing Green v Mills).

16. 189 U.S. at 486 .

17. Giles Brief at 7 .

18. 189 U.S. at 494.

19. Charles A. Heckman, Keeping Legal History "Legal" and Judicial Activism in Perspective: A Reply to Richard Pildes, 19 Const. Comm. 637 (2002).
} 
Holmes, not seeing things the way Professor Heckman does today, went on to address the "final considerations" that he asserted had to be confronted to deal properly with the "new and extraordinary situation" Giles in fact presented. Fully appreciating the context of Giles, Holmes addressed those "final considerations" with justifications themselves so final in character as to still, more than 100 years later, take a reader's breath away:

The bill imports that the great mass of the white population intends to keep the blacks from voting. To meet such an intent something more than ordering the plaintiff's name to be inscribed upon the lists of 1902 will be needed. If the conspiracy and the intent exist, a name on a piece of paper will not defeat them. Unless we are prepared to supervise the voting in that State by officers of the court, it seems to us that all the plaintiff could get from equity would be an empty form. Apart from damages to the individual, relief from a great political wrong, if done, as alleged, by the people of a state and the State itself, must be given them by the legislative and political department of the Government of the United States. Decree affirmed. ${ }^{20}$

If this is not a death-knell to any effort to persuade federal courts to enforce the Fifteenth Amendment against massive, racialized disfranchisement, it is hard to know what would be. Newspaper editorials and academic commentators of the time certainly took Giles as exactly that. The Canon noted, for example, that the New York Daily Tribune desperately cried out: "Somewhere, somehow, there must be a way of passing on the constitutionality of State laws which plainly nullify the spirit of the federal Constitution...." ${ }^{21}$ But as the plaintive tone of the editorial suggested, Holmes had made clear there was no such way.

Academic commentary in the American Political Science Review construed Giles as providing "the real explanation of the difficulty in the way of those who seek through the courts to compel the dominant race in a great section of the country to do that which that race is almost unanimously determined it will not do." 22 In the legal scholarship of the era, a Harvard Law Review article, after noting the Mills case, nonetheless went on to remark that "[b]y far the most significant recent case is that of

\footnotetext{
20. 189 U.S. at 488.

21. Pildes, 17 Const. Comm. at 312 (cited in note 3 ).

22. John C. Rose, Negro Suffrage: The Constitutional Point of View, 1 Am. Pol. Sci. Rev. 17, 39 (1906).
} 
Giles v. Harris ... [which reveals that] equity considers her machinery too lame and impotent to attempt such a gigantic task as preventing the people of a state from so administering a law, fair upon its face, as to effect a fraudulent discrimination on account of race." 23 Similarly, a Columbia Law Review article "admitted" that Giles and a follow-up case, Giles v. Teasley, ${ }^{24}$ "have made it quite difficult to bring the question [of whether the disfranchising constitutions violated the Fifteenth Amendment] squarely before the Supreme Court..."25 None of these articles suggested that Mills offered any comparable obstacle. If any actor of the time saw Giles as "basically concerned with procedural issues of no lasting consequence," I have not run across that figure. Nor does Professor Heckman offer any such evidence from a single figure of the period; Professor Heckman focuses only on the formal texts of the opinion, rather than on the political and social context in which those decisions took on meaning.

To black activists seeking to stave off the elimination of black political participation, Giles must have been devastating. In many states, federal court litigation had been looked to for several years as the last, best chance to defeat disfranchisement - especially within the black community. Whites who also resisted disfranchisement often encouraged blacks to stay out of the political phase of the struggle over disfranchisement; the fear was that black participation would countermobilize more aggressive white support. In North Carolina, for example, Republican Party leaders, though fighting disfranchisement, dissuaded black leaders from mobilizing opposition during the 1900 campaign for popular approval of the constitutional disfranchising amendments. ${ }^{26}$ These leaders expressly held out as their last hope that, if the amendments were adopted, the courts would find the provisions unconstitutional (note that this hope remained alive long after Mills $v$. Green had been decided). Given that federal courts were held out as the alternative to political struggle, even as late as 1900 , one can only imagine the despair that Giles must have engendered in the black community.

23. Julien C. Monnet, The Latest Phase of Negro Disfranchisement, 26 Harv. L. Rev. 42, 53, 54 (1912-13).

24. 193 U.S. 146 (1904).

25. See also William C. Coleman, The Fifieenth Amendment, 10 Colum. L. Rev. 416,448 n.73 (1910). The quotation goes on to say: "but it is thoroughly believed that court ... will, if necessary, make every endeavor to meet the question squarely, even to the extent of modifying or over-ruling a former decision."

26. Glenda Elizabeth Gilmore, Gender \& Jim Crow: Women and the Politics of White Supremacy in North Carolina, 1896-1920 at 123 (U. of North Carolina Press, 1996). 
Why does Professor Heckman assert that, despite all this, Giles was of no real moment? Primarily, it seems, because Giles arose in what he calls a "complicated procedural posture." Professor Heckman then focuses only on these procedural and technical issues of jurisdiction and pleading. Professor Heckman expresses disagreement or puzzlement at how the Court handled these procedural questions. But this mystery is easy to unravel by keeping an eye on the larger prize. The Court brushed aside each procedural claim, sometimes with tortured logic, precisely so that the Court could issue a definitive ruling on the critical substantive question on which everything turned: that there would be no injunctive relief to protect political rights even when massive, racialized, constitutional disfranchisement was at stake. If the Court had merely addressed preliminary procedural issues, so that the challenge to disfranchisement was left alive and only postponed to another day, that would have been a different matter. But the key to the actual significance of Giles is in the Court's statement that the essential context is that "the great mass of the white population intends to keep the blacks from voting," and the Court's response that, in such a context, any order from the courts would be "an empty form." That is not a statement about procedural niceties; it is a stark notice that the end of the line has been reached. The Canon was not inattentive to the procedural issues; ${ }^{27}$ but these issues have nothing to do with the political, legal, social, or historical significance of Giles.

27. Pildes, 17 Const. Comm. at $305 \mathrm{n} .44$ (cited in note 3). I do accept one of Professor Heckman's technical points. I wrote that Holmes found that the complaint did allege the requisite amount in controversy. Formally speaking, as Professor Heckman points out, Holmes seems to have treated as a mere technicality a proper allegation of the jurisdictional amount either because no objection had been raised on this ground, or because the complaint could easily be amended, on a remand, to meet this requirement, given that it was well established that deprivations of the right to vote for one individual could exceed the then-jurisdictional amount of $\$ 2,000$.

On the other hand, I am not sure what point Professor Heckman means to make in referring at length to the dissenting opinions. Justice Harlan did conclude that, if he reached the merits, he would permit the Giles litigation to go to trial, as did Justice Brewer. But Justice Harlan urged the Court to dismiss for lack of jurisdiction. It is hardly uncommon, of course, for Justices on the losing side of what Justice Harlan rightly called "questions of considerable importance" to urge the Court to dispose of the case on procedural grounds, so that the battle might be faced another, perhaps more favorable, day. By urging that the case be allowed to go to trial, and that the issue of proper remedy be left for another day, Justice Brewer too might be thought to have been temporizing. I gather Professor Heckman wants to read these dissents as rejecting Giles' claims for equitable relief, and hence agreeing with the Court majority on the critical issue, but the dissents do not say that and can hardly be taken to imply that. Had Justice Harlan or others in dissent agreed with the Court's holding on the unavailability of equitable relief 
A second reason Professor Heckman thinks Giles unimportant is his view that Mills $v$. Green had already done all the dirty work. He bases his view not on anything said in the United States Supreme Court, but on the three-judge panel decision in the Circuit Court of Appeals, in a case titled Green v. Mills. ${ }^{28}$ The context was a challenge to South Carolina's registration scheme for a referendum on whether to call a constitutional convention. But the claim was not a race-based challenge under the Fourteenth or Fifteenth Amendments and the plaintiff was not identified in the pleadings as either white or black; as the Circuit Court expressly noted, "No discrimination on account of race, color, or previous condition of servitude is charged, or pointed out as deducible on the face of the acts in question." ${ }^{29}$ Even this lower-court decision, in fact, seems to go out of its way to qualify the decision and signal that this was not a case that tested the massive, racialized disfranchisement in state constitutions that to this point, had only been accomplished in Mississippi. ${ }^{30}$ The Circuit Court opinion rejecting the plaintiff's claims, written by Supreme Court Chief Justice Fuller sitting as circuit justice, did hold that equitable relief was not available to enforce political rights. Given that the context was so far removed from Giles, as the plaintiff and lower court framed the issue, it would surely be hard to see this decision, even had the Supreme Court upheld the decision, as the burial ceremony for a head-on confrontation with racialized, massive disfranchisement. But, as noted above, when Green v. Mills reached the Supreme Court, it was decided on entirely different grounds: the Court merely dismissed the case as moot in a brief, unanimous opinion. Given that the lower court made clear it was not addressing a race-based challenge under the Reconstruction Amendments, and that the Supreme Court completely bypassed the lower court's substantive holding

in the case, it would have been easy enough to say so directly.

28. 69 F. 852 (1895).

29. Id. at 859 .

30. Consider the long qualification to the decision in the concurring opinion:

There is nothing in the record to show that the complainant is a man of color, or that those for whom he sues are colored persons. The bill contains no allegation that the provisions of law complained of were devised against the complainant, or those for whom he sues, on account of their race, color, or previous condition of servitude. There is nothing in the averments of the bill from which it may naturally, or must necessarily, be inferred that the complainant, and those for whom he sues, are citizens of color. There are no averments in the bill which show that the case falls within the purview of the fifteenth amendment of the constitution of the United States. Nor does the bill contain any allegations which raise a federal question under [the equal protection clause.].

Id. at 862 (Hughes, J., concurring). 
about voting-rights remedies in favor of a unanimous mootness decision, a reader (at the time or today) might be forgiven for concluding that the Court was leaving itself options about how to respond to massive disfranchisement, should that tactic be adopted beyond Mississippi and a case directly presenting the issues come to the Court. But one need not go that far to wonder how Professor Heckman can conclude that the Court of Appeals decision in Mills effectively barred the way for litigation challenges to the disfranchisement that spread throughout the South in the late 1890 s.

Moreover, when, in the 1960 s, the federal courts eventually began to dismantle the disfranchisement system created by the Alabama Constitution of 1901, they called Giles "the most formidable" obstacle they faced in asserting authority to order black voters registered. ${ }^{31}$ They called the principle that equity could not remedy political wrongs Justice Holmes's "somewhat celebrated dictum" in Giles v. Harris. ${ }^{32}$ They did not mention Mills v. Green. When the Court also refused for many years to stay out of one of the other major challenges to the design of democratic institutions, the problem of overwhelming malapportionment, it was Giles v. Harris that Justices Frankfurter and Black debated in arguing about whether such challenges should be non-justiciable. ${ }^{33}$ Mills v. Green was nowhere to be seen.

Even at the time, Southern disfranchisers did not seem to take Mills v. Green as the open license Professor Heckman considers it. Long after Mills, Southern disfranchising conventions worried expressely about whether their work would survive challenge under the Reconstruction Amendments; suffrage provisions were self-consciously crafted to minimize the risk, perceived as real, that the federal courts would invalidate them. There is one decision, which postdates Mills by three years, that, unlike Mills, might be thought to have a plausible claim to being as significant as Giles; that is the decision in Williams v. Mississippi. ${ }^{34}$ But even after Williams, Southern disfranchisers continued to worry about the federal courts and shaped their actions so as to minimize the risk of federal judicial reaction. They worried

31. State of Alabama v. United States, 304 F.2d 583, 592 (5th Cir. 1962).

32. Id.

33. Compare Colegrove v. Green, 328 U.S. 549, 552 (1946) (Frankfurter, J., announcing the judgment of the Court) (plurality opinion) (invoking Giles to conclude that claims of political right were not justiciable) with id. at 567 (Black, J., dissenting) (distinguishing Giles v. Harris).

34. 170 U.S. 213 (1898), discussed in Pildes, 17 Const. Comm. at $298 \mathrm{n} .12$ (cited in note 3). 
that Williams, which involved the first challenge to disfranchisement, had failed only because the plaintiff had not been able to prove adequately the racially discriminatory practices he alleged. ${ }^{35}$ We should not forget that even in 1903, three Justices were prepared to let the Giles case go to trial. ${ }^{36}$ The critical actors of the era acted as if Mills had wrought no drastic change. After Giles, however, no one could have missed the messageand no one did.

Finally, Professor Heckman takes issue with the sociopolitical question of whether a different outcome in Giles could plausibly have influenced the political dynamics in a way that would have affected the outcome of disfranchisement struggles. In The Canon, I sought to document how recent and fragile the white electoral majorities were that approved disfranchisement in a border state like North Carolina, and how even in the deepest South, the disfranchising constitution of Alabama was adopted by a thin, nominal majority itself made possible only by overwhelming fraud. The point was to suggest that the final and ultimate entrenchment of disfranchisement, far from being the inevitable product of Southern majoritarianism, took form only by the narrowest of margins, if in fact popularly endorsed at all. Yet once the Southern electorate had been drastically constricted through these new constitutional provisions, these narrow electoral (or fabricated electoral) margins were leveraged into essentially unchallengeable and long-enduring political power.

Once the reality of a precarious, contested, factional struggle for control over the future of Southern politics even among whites is recognized, we can question Holmes's imagery of a ro-

35. Kousser, Colorblind Injustice at 322 (cited in note 11). In this respect, Kousser, writing many years later, disagrees with Vann Woodward, who does see Williams v. Mississippi as having been of greater significance at the time. C. Vann Woodward, Origins of the New South, 1877-1913 at 322 (Louisiana State U. Press, 1951).

36. Professor Heckman argues that had Giles come out differently, the case would have been a footnote even in my canon, as the consequence would have been "merely" to send the case to trial. This is much like saying had the Supreme Court held the constitutionality of the Vietnam War a justiciable question, such a decision would "merely" have sent the case to trial. Well, yes. But the significance of sending Giles to trial would be far greater than even this Vietnam War claim; the latter posed complex constitutional questions on the merits. Yet there was no great factual mystery as to what states like Alabama were doing with disfranchisement; the decisive question was whether federal courts had the power to provide a remedy. Had the Court required that the case proceed to trial, the trial outcome might have been relatively foreordained; much would have depended, of course, on the exact terms of any such Court decision. I would hope it is clear that when I refer to a countrary decision, in which the Court would have "upheld" Giles's claims, I am referring to the underlying, substantive issues in the Giles litigation, not the preliminary procedural issues on which Professor Heckman focuses. 
mantic, but tragic Supreme Court staying its hand only because faced with an insurmountable, unified white South. As the great Southern historian C. Vann Woodward revealed long ago, "Behind the 'White Supremacy' slogans and the front of racial solidarity, there raged a struggle between Southern white men that is usually overlooked." ${ }^{37}$ Had the federal courts invalidated the 1901 Alabama Constitution (whether that decision was actively enforced or not), who knows what configuration Alabama's politics would have taken, in this always turbulent era, at the next moment at which the issue might have been pressed? At decisive historical moments, with political forces closely balanced, small pushes can tip events down one road that later comes to seem foreordained.

Professor Heckman does not challenge my account of North Carolina and Alabama. But he mistakenly believes the account I offer stops in those states; because I discuss the dynamics of political struggle only in North Carolina and Alabama, he concludes, much to my surprise, that The Canon "does not profess to see hope" of a similar sort elsewhere.$^{38}$ Of course, one might think that, had disfranchisement been reversed in North Carolina and Alabama, such a dramatic reversal would have left a mark everywhere else. But more importantly, I did not discuss other states at all; I had hoped to make the point without entering too deeply the fascinating but detailed bogs of 19th century politics in every Southern state. North Carolina and Alabama were meant to be only exemplary in The Canon, one a state from the border region, the other from the deep South and the focus of the Giles litigation. Professor Heckman's challenge presses me to say a few words about politics elsewhere. For it turns out that disfranchisement was so controversial in most places that political leaders did not even have the nerve, as in Alabama, to go through the pretense of taking the issue to the electorate. In other words, Alabama, where massive electoral fraud was essential to adopting disfranchisement, involved probably the most democratic process by which constitutional disfranchisement occurred.

Mississippi, the leader in disfranchisement through the technique of adopting a new, post-Reconstruction state constitution, held a constitutional convention composed of 130 Democ-

37. C. Vann Woodward first revealed this dynamic in Origins of the New South at 327 (cited in note 35). Woodward went on to observe: "The real question was which whites should be supreme." Id. at 328.

38. Heckman, 19 Const. Comm. at 639 (cited in note 19). 
rats and a sum total of four men from other parties. ${ }^{39}$ The movement for the convention itself was "strictly a movement by the elite, which did not reflect any general demand for disfranchisement." ${ }^{, 40}$ Even so, the suffrage restrictions proposed split delegates along white-county and black-county lines; the former opposed disfranchisement. At one and the same time, the new constitution would radically reduce the electorate, eliminate black voters, and transfer power among whites into the hands of the elite planters of the black counties. "The Mississippi press bitterly attacked the franchise provision as a fraud and a disgrace." ${ }^{\prime 41}$ As for public opinion, thirty-four papers, all but one of the leading ones in the state, came out in absolute opposition to the new constitution. ${ }^{42}$ Before this time, the prevailing practice in Southern states, other than during and right after the Civil War, had been to submit new constitutions for popular approval. But when the extensive hostility to the proposed new constitution became clear, the delegates to the convention decided that it was "unnecessary and inexpedient" to submit the constitution for popular ratification. Instead, they just went ahead and proclaimed it to be in effect-and got away with that.

Mississippi became, then, a model for bypassing the electorate-even the white electorate-as a way of enshrining disfranchisement. Virginia proponents had twice tried and failed to get popular consent for a convention; in the most recent defeat, just three years before a convention was in fact called, the popular vote had been 83,453 against a convention and 38,326 in favor. ${ }^{43}$ To allay widely shared concerns, Virginia's General Assembly then authorized a convention and election of delegates but also required, in that same law, that any new constitution be submitted for popular approval. In another important act, the Democratic Party, leading the charge for a convention, also committed to popular ratification in its electoral platform. But while the convention was debating ratification, the popular vote in Alabama took place; as described in The Canon, the Alabama disfranchising constitution was rejected in the white counties and adopted only because it won overwhelming-and obviously fraudulently-majorities in the black counties. Virginia's dele-

39. J. Morgan Kousser, The Shaping Southern Politics: Suffrage Restriction and the Establishment of the One-Party South, 1880-1910 at 142 (Yale U. Press, 1974).

40. Id. at 142.

41. Van Woodward, Origins of the New South at 341 (cited in note 35).

42. Id. 1902).

43. J.N. Brenaman, A History of Virginia Conventions 82 (J.L. Hill Printing Co., 
gates took note of the Alabama experience, and by a small majority, Virginia's elites defied both state law and the commitment to party members and simply, as in Mississippi, proclaimed the constitution law without any popular referendum. No valid Virginia constitution since 1776 had been adopted without popular submission and vote-but the disfranchising convention got away with this ploy. ${ }^{44}$

Virginia, Mississippi, Alabama, North Carolina: the pattern of how constitutional disfranchisement was achieved should be clear. I will not belabor the point by going through the record in other disfranchising states. ${ }^{45}$ To entrench disfranchisement into enduring, constitutional form, the oligarchic Southern elite had to lie, steal votes on a massive scale, or control a disfranchising convention and then avoid popular ratification at all costs. The success of these constitutions, thus, hung by a fragile thread; far from inevitable, popular support did not even exist in many states. My point is not that most whites would have been unhappy had black voting been eliminated; a majority surely would have been. But it was not easy to disfranchise blacks without raising the serious possibility (which became the reality) that many whites would be written out of politics too. The Fifteenth Amendment was still considered a barrier to franchise rules that were explicitly written along racial lines. But poll taxes would burden poor whites as much as poor blacks; literacy and understanding tests contained the risk of eliminating illiterate whites as well. And because disfranchisement favored the Democratic Party, other parties, such as Republicans, Populists, and Greenbackers, often resisted. Politics is coalition building; disfran-

44. On the history of prior Virginia constitutions and the debate over proclamation versus submission in 1901-02, see Paul Clipman McDanel, The Virginia Constitutional Convention of 1901-1902 at 113-136 (Johns Hopkins U. Press, 1928). This leading study from within a generation of the events concludes: "Although it is impossible to say conclusively that the constitution would have been rejected had it been submitted to the people, the general opinion is that it would have been.... the negro vote could have been handled as in the past [by fraudulently "counting it in" for the constitution], but that the opposition of the Republicans and the disaffected elements in the Democratic party could have been overcome is doubtful." Id. at 129 . This study also concludes that the new constitution had delivered control of the state into the hands of less than 10 percent of its citizens, id. at 58-and this from an author who concludes nonetheless that "the radical restriction of the suffrage was a necessity." Id. at 154.

45. As a brief example from yet one more state, consider South Carolina: only 38 percent of white voters there voted in the referendum for a disfranchising constitution, which passed only by 31,402 votes to 29,523 votes - despite widespread fraud designed to get the referendum passed. Again, in this deep South state, "the impetus for disfranchisement derived not from the masses, but from a fairly small elite." Kousser, Shaping Southern Politics at 148-49 (cited in note 39). 
chisement affected enough interests that strong coalitions existed against it, regardless of how some members of those coalitions might have felt about black suffrage alone. Because disfranchisement constitutions were such a precarious "success" in so many states, had the Supreme Court in Giles invalidated the Alabama Constitution of 1901 , it is entirely speculative how these battles would have come out in different years, with evershifting political dynamics, in the various states.

\section{III}

Shifting from historical interpretation to contemporary constitutional theory, Professor Heckman cautions against criticizing Giles, lest we open the door to all manner of judicial tampering with politics, including actions as surprising as Supreme Court resolution of a disputed Presidential election. This is the slipperiest slope I have seen worried about in some time: the line from Giles to Bush v. Gore hardly need be so precipitous. Nonetheless, I do agree with the general nature of Professor Heckman's concern. As constitutional law has shaken off the legacy of Giles and come to play a major role in overseeing democratic politics in the last 40 years, the task for judges and scholars is to develop an acceptable theoretical framework for specifying the kinds of circumstances, factors, and triggering principles in which constitutional law should aggressively scrutinize the ground rules of democracy-and when constitutional law should leave democratic processes to self-scrutiny. Much of my own work in recent years has been directed to precisely these questions concerning a proper theoretical understanding of the contours a "constitutional law of democracy" ought to have. ${ }^{46}$ Perhaps it will provide some comfort to Professor Heckman to learn that I have criticized the Warren, Burger, and Rehnquist Courts for failing to conceive these boundary lines appropriately.

But a constitutional practice and theory that could not distinguish between one of the most systemic, transparent, and massive violations of clear constitutional principle and text in American history - the disfranchisement movement - and other

46. See, e.g., Richard H. Pildes, Constitutionalizing Democratic Politics, in a Badly Flawed Election (Ronald Dworkin ed. 2002); Richard H. Pildes, Democracy and Disorder, 68 U. Chi. L. Rev.695 (2001); Richard H. Pildes, The Theory of Political Competition, 85 U. Va. L. Rev. 1605 (1999); Samuel Issacharoff and Richard H. Pildes, Politics as Markets: Partisan Lockups of the Democratic Process, 50 Stan. L. Rev. 643 (1998). 
contexts in which constitutional law is appealed to today to invalidate certain democratic processes would be a constitutional system in pathological condition. Difficult boundary issues abound regarding when constitutional law should overturn political structures and when there is insufficient justification to do so. ${ }^{47}$ But in terms of constitutional principle, disfranchisement is not one of them. We can debate the essentially political and strategic judgments about whether the Court would have done more harm than good had it reached a contrary result in Giles. But in terms of constitutional principle and theory, there seems to me nothing at all to say, other than that disfranchisement was one of the baldest, most systemic violations of straightforward constitutional command in American history. If constitutional law and judicial review do not exist to hold that the blatant, race-based elimination of citizens between 1890-1908 from even the formal right to vote violated the legal meaning of the Reconstruction Amendments, it is hard to know what constitutional law exists for at all.

47. This is perhaps the central theme explored throughout my casebook. See Samuel Issacharoff, Pamela S. Karlan, and Richard H. Pildes, The Law of Democracy: Legal Regulation of the Political Process (Foundation Press, 2nd ed. 2002). 